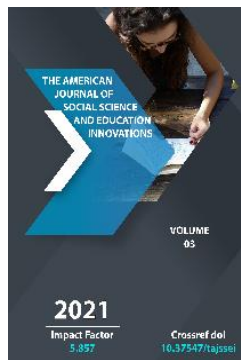

\title{
The History Of People's Rebellions In Ferghana Region (Based On Materials Of The National Archive Of Uzbekistan)
}

\author{
Doniyorbek Murodjon Ugli Sobirov
}

Andizhan State University, Faculty Of History, 3rd Year Student Of Archival Studies, Andizhan Region, Republic Of Uzbekistan

\section{Journal Website:} http://usajournalshub.c om/index,php/tajssei

Copyright: Original content from this work may be used under the terms of the creative commons attributes 4.0 licence.

\section{ABSTRACT}

The article deals with the people's uprisings, which played an important role in Uzbek historiography, in particular, the uprising against the unjust verdict in Ferghana region on August 31, 1898, its origin, historical circumstances, the participants scientifically analyzed of the uprising using materials from the National Archives of Uzbekistan.

\section{KEYWORDS}

Ferghana region, uprising, trial, court verdict, leader of the uprising, Margilan district, Osh district.

\section{INTRODUCTION}

Sources in Uzbek historiography, especially archival sources based on primary data, play a leading role. In particular, the I.1 fund of the National Archives of Uzbekistan is called the
Chancellery of the Governor-General of Turkestan, which contains information about the participants of the uprising against the verdict in the Ferghana region. This 
information is not yet fully reflected in Uzbek historiography, and in this article we have discussed in detail the causes and historical conditions of the uprising. Thus, the whole nation should care about the spirituality of the nation. In a speech to the UNESCO Executive Board in Paris, the first President of Uzbekistan, Islam Karimov, said: "For centuries, our country has been one of the cradles of world civilization" [1, p.45] Thanks to independence, our spiritual values, the legacy of our ancestors, began to be restored in all its perfection, without being cut, without being stuck in the so-called "progressivereactionary" violent stereotypes. The Holy Quran and Hadiths were first translated into Uzbek and published in the other "Soviet period" even the works of our scholars, whose names were forbidden to be remembered, were published one after another, and began to reach the hands of thirsty readers. The law on the state language was adopted. While the Russian Empire tried to keep our spirituality in a state of stagnation, the Bolshevik chauvinists pursued a policy of completely alienating the local peoples from their national spirituality. "Soviet culture" was built on the basis of complete hypocrisy. They rejected the religion, the millennial beliefs of the people, and instead faced the scourge of "cult of personality." The struggle for "cotton independence" has led the peoples of Turkestan to economic dependence and impoverishment, the destruction of the nature of the region, the poisoning of water, air and soil.

The anniversaries of the mystics - Ahmad Yassavi, Najmiddin Kubro, Bahovuddin Naqshband - evoked feelings of purification in the spirit of our nation. The erection of a magnificent monument to our great ancestor Amir Temur in the very center of the capital has given an indelible light to the spirit of pride of every child of the Uzbek people. At the beginning of the 2oth century, our modern scholars, who led the nation to enlightenment, justice and freedom, began to take a worthy place in the hearts of the people. The members of the national liberation movement, widely condemned as "oppressors," were praised. It is no coincidence that today we are beginning to seriously study our national spirituality on a theoretical basis. The culture and spirituality of the Uzbek people have never developed in a separate way from the world culture and spirituality. He has always enriched the world culture by creatively mastering the spiritual wealth of other nations [2, p.78]. At the same time, our nation has its own independent spiritual image, which has been formed for centuries, maybe thousands of years, it is not alien to universal values, but has its own interpretations, its own approach, its own understanding of the supreme truth of Being.

\section{METHODS}

The presented scientific article comprehensively uses the principles of history and methods of comparative analysis, which play an important role in modern historiography. Based on these methods, an objective assessment of the historical events was made, as well as the relevant conclusions were drawn with the help of preliminary information about the participants in the uprising. However, most of the information presented in the article has a primary basis, has not been reflected in the scientific research and studies created to date, and has been included in scientific consumption for the first time. 


\section{RESULTS AND DISCUSSIONS}

About the participants in the uprising in the Ferghana region who hid from the investigation and the court Abdujalil Mirsaid Kariev, a native of the Andizhan mountains, Mulla Yunus of the Margelan district, Marraim (Magomet Ibragimov) from the Osh district, Türkbai Arzy kul oglu from the village Khanabad, Margelan district.

During the investigation and trial in the case of the uprising of the natives of the Ferghana region, many of the participants in the conspiracy of the Mintyubinskiy Ishan and those suspected of being involved in a crime fled to trial and punishment. 1898 August 31 was followed by the Imperial command to prosecute only the most important of those hiding in relation to the rest, were given to apply administrative measures, at the discretion of the power of Your Excellency [3, p.3].

In the types of execution of such a High command and in accordance with the order given to me by your superiority, I, in consultation with the military investigator Colonel Nekrasov, present the lower name list to those natives who participated in the uprising, who, according to their role and vigorous activity in conspiracies and uprisings, should, in my opinion, be punished according to all the severity of the law, namely:

1. Abdujalil Mirsodik Kariev - a native of the city of Andizhan, this native with his young mother lived permanently in Mecca and Constantinople, appearing in his homeland for the last time he made a profit in Fergana at the beginning of this year, brought with him the religion of the prophet's hair and beard, collecting abundant dan in the believers native
Muslim; appeared in Andijan but immediately left, noting that the local administration paid attention to his exploitation of the religious feeling of the people and settled in Sharikhan of the Margelan district, where he lived all the time until the end of May, when he left through Osh to Koshgar. The true role in the uprising was revealed only later from the generations of the pardoned Makambay Kokibaev (fol. 568, 5921664 Andizhan investigation), who showed that Abdujalil rescued the Mintyubinskiy Ishan Magomed or the decision to declare a holy war against the Russians, assuring Ishan that this was followed by the order of Saltan. confirmation of which he presented to Ishan and his relatives the well-known "Sultan"s letter" and gave the worn robe, allegedly given to Ishan by the Sultan from his shoulder. The incitement of Abdujalil is confirmed by Ishan himself, who only refrained from giving his name; with certainty and details, the participation of Abdujalil is established by the testimony of Inayatkhan, who was personally present at Ishan's meeting with Abdujalil in the Tajiks (p. 891st Andijan investigation). Immediately upon the discovery of Abdujalil's guilt, the military investigator made the subject to be searched and detained in Kashgar, but there is still no information about his drinking bowls and it is possible to say with confidence that he managed to return to the Turkish border through India.

2. Mulla Kasym Arabbaev and Kal Musurman Mulla Saibov (Both from the Karakurgan Kulinskaya Voslost of the Margelan district).

3. Mulla Yunus from Shiman of the same volost. All these three natives were active 
assistants of Ishan and the executed volost ruler Gaib Nazar in organizing a conspiracy, gathering participants in the uprising and in the attack on Andijan itself, and they were chiefs of small detachments, and Mulla Kasym and Kal Musurman also took an active part in the attack on Kulinsky's house people's judge Mulla Yuldash in the murder of Bychkov. The guilt of Mulla Kasym and Kal Musurman was established by the testimony of Gaib Nazar, Khudaykul Rakhmankulov, Mulla Yuldash, Madmuss Kara bala ugli, Tokhtabay, Irgashbai and Makimbay Kokibayev, and Khudaykul Rakhmankulov's testimony about the participation of Mulla Yunus is testimony to the investigation.

4. Madraim (Magomed Ibragimov) Chairman from the Naukat volost of the Osh district. He was appointed by Ishan Rais (guardian of morality and purity of faith) to some Kyrgyz districts of the Naukat volost, participated in the conspiracy, taking part in a meeting in Tajik on May 14 or 15 this year, where he went to Ishan with Umarbek and others, and then became an active organizer gatherings of conspirators on Ak Terek to attack Osh. Upon discovery of the conspiracy, he immediately fled, met in the mountains with Inoyatkhan, entered Karategin with him, was detained by the Bular people in Nabadian, and then on the way to Samarkand, escaped again and has not yet been sought. His guilt is confirmed by a whole series of testimonies of the accused and witnesses on sheets 129, 133 about, 136 about and others., Of the Osh investigation proceeding.

5. Shirmat khalfa Tashpalvanov - a resident of the Khoja aryk, Yakkatut volost, Margelan district. His activity as the closest assistant to Inoyatkhan in arranging shalyams and organizing a conspiracy to attack Margelan, is visible from the previously presented many conclusions about Inoyatkhan and Tashsufi and is confirmed by the same testimony [4, p.6].

6. Turkbay Arzikul ugli - a resident of Khanabad, Margelan district. The son of Arzikul Pansat, one of the main figures of the Margelan group of the accused, is exposed by the testimony of two prominent figures of the uprising and accomplices of Tashsufi Mulla Taji ugli and Inoyatkhan, from which it is clear that Turkbai not only participated in the conspiracies of Shaikh Inayathobyan, but also took a direct part in the murders of Kuchshyts Suleiman between Kuva and Asake. I present the above at the discretion and depending order of Your Excellency.

\section{CONCLUSION}

Occupied by Tsarist Russia, Turkestan and Ferghana became a shining example of colonial oppression. The deterioration of the living conditions of the local people, the trampling of national and religious values, the rapid inflow of foreign investment into the country, the brutal plunder of the country's wealth by the invaders did not leave indifferent progressive intellectuals. Therefore, the national patriotic intelligentsia sought various ways to get rid of the effects of colonialism and fight for development. As a result of these efforts, the some movement emerged in the valley at the end of the 19th century. During this time, as in the whole of Turkestan, the process of division into different groups among the intelligentsia of the valley accelerated. Despite the differences of opinion, the intellectuals of the region were united by the idea of a single Turkestan independence. 


\section{REFERENCES}

1. Karimov I.A. High morality - an invincible power. -Tashkent: Ma'naviyat, 2008.

2. Imomnazarov M.S. Stages of development of our national spirituality. -Tashkent, 1996.

3. National Archive of the Republic of Uzbekistan, I-1-Fund, List-31, Work-72.

4. National Archive of the Republic of Uzbekistan, I-1-Fund, List-34, Work-82. 